\title{
PENGUKURAN KINERJA PERUSAHAAN DENGAN PENDEKATAN BALANCED SCORECARD PADA PT. INDO-RAMA SYNTHETICS TBK.
}

\author{
Santos \\ Program Studi Magister Manajemen Universitas Tarumanagara
}

\begin{abstract}
Abstrak : Penelitian ini bertujuan untuk mengetahui pembobotan perspektif Balanced Scorecard (BSC) menggunakan Analytical Hierarchy Process (AHP), untuk mengetahui pengukuran kinerja berdasarkan skor dari perspektif BSC, danuntuk mengetahui apakah indikator kinerja memerlukan suatu perbaikan atau tidakberdasarkan Traffic Light System pada PT. Indo-Rama Synthetics Tbk.Jenis penelitian adalah deskriptif dan periode penelitian dari bulan Mei sampai dengan Oktober 2018. Pengumpulan data dilakukan melalui wawancara dan penyebaran kuesioner kepada manajer, karyawan dan pelanggan. Alat analisis yang digunakan adalah BSC dan AHP dengan software Expert Choice 11. Hasil penelitian menunjukkan hasil pembobotan menggunakan AHP, perspektif pelanggan dan finansial adalah perspektif kunci yang sangat mendorong kinerja PT. Indo-Rama Synthetics Tbk., selain itu, kualitas layanan, dukungan pelanggan, rasio profitabilitas, rasio likuiditas dan penguasaan pasar adalah lima kriteria pertama untuk evaluasi kinerja PT. Indo-Rama Synthetics Tbk. Berdasarkan skor dari perspektif BSC, perspektif finansial, pelanggan, dan proses bisnis internal memiliki kinerja baik, sedangkan perspektif pembelajaran dan pertumbuhan memiliki kinerja sedang. Berdasarkan traffic light system, secara keseluruhan indeks total kinerja PT. Indo-Rama Synthetics Tbk. memiliki warna hijau, artinya perusahaan telah mencapai kinerja yang diharapkan, namundari sisi strategy objective fasilitas pendukung masih berwarna merah, hal ini menunjukan kinerja yang sangat buruk, olehkarena itu pihak perusahaan harus sesegera mungkin memperbaiki.
\end{abstract}

Kata Kunci : Analytical Hierarchy Process, Balanced Scorecard, Pengukuran Kinerja, Traffic Light System

\section{PENDAHULUAN}

Kinerja adalah merupakan suatu pencapaian terakhir sebuah perusahaan yang diharapkan semakin baik dan meningkat dari periode ke periode berikutnya. Kinerja sering dijadikan tolak ukur keberhasilan suatu perusahaan. Pengukuran kinerja yang akurat tentunya akan mempengaruhi keberlangsungan dan daya saing perusahaan yang bersangkutan. Penentuan metode atau pendekatan yang tepat akan menentukan keakuratan pengukuran kinerja tersebut. Adapun aspek kinerja yang paling umum dijadikan tolok ukur kinerja sebuah perusahaan adalah kinerja finansial. Aspek finansial berkaitan dengan kegiatan pengelolaan cara mendapatkan dana dan bagaimana memanfaatkan dana tersebut secara efektif dan efisien.

Berakaitan dengan permasalahan pengukuran kinerja tersebut, dikembangkanlah suatu alat pengukuran yang lebih komprehensif oleh Kaplan dan Norton (1996) yang sering disebut sebagai Balance Scorecard. Dalam konsep Balance Scorecard, dilakukan pengukuran kinerja yang menyeimbangkan tolak ukur keuangan dan non-keuangan. Balance Scorecard dirancang untuk memanfaatkan seluruh sumber daya yang ada serta menekankan bahwa ukuran keuangan dan non-keuangan menjadi bagian sistem informasi yang dipakai oleh karyawan di semua tingkatan dalam perusahaan. Dengan pengukuran ini diharapkan perusahaan dapat menetapkan strategi dan berjalan secara efektif dan efisien dalam memenangkan persaingan, serta memberikan keyakinan adanya keseimbangan antara kepentingan stakeholder dengan kepuasan pelanggan dengan cara memperbaiki proses bisnis internal, serta pembelajaran dan pertumbuhan. 
Dalam upaya membantu mengantisipasi perubahan lingkungan, meningkatkan kinerja serta meningkatkan daya saing perusahaan, dalam penelitian ini penulis akan menerapkan penggunaan Balance Scorecard untuk mengukur kinerja PT. Indo-Rama Synthetics Tbk serta menganalisis dari hasil pengukuran tersebut untuk selanjutnya dijadikan bahan masukan bagi perusahaan.

Berdasarkan latar belakang masalah di atas, maka tujuan dalam penelitian ini adalah untuk memperoleh hasil temuan mengenai: (1) pembobotan perspektif Balanced Scorecard (BSC) menggunakan Analytical Hierarchy Process (AHP), (2) pengukuran kinerja berdasarkan skor dari perspektif Balanced Scorecard BSC, dan (3) apakah indikator kinerja memerlukan suatu perbaikan atau tidak berdasarkan Traffic Light System.

\section{LANDASAN TEORI}

\section{Balanced Scorecard}

Balanced Scorecard adalah sebuah perencanaan strategik dan sistem manajemen yang sangat sering digunakan di dalam suatu bisnis dan industri, pemerintahan, dan organisasi nonprofit di dunia (Rufaidah, 2012). Konsep Balanced Scorecard (BSC) diusulkan oleh David Norton, CEO Nolan Norton Institute, dan Robert Kaplan, seorang profesor di Harvard University. Konsep ini pertama kali diimplementasikan sebagai sistem evaluasi kinerja, terutama untuk 12 perusahaan di Amerika Serikat pada tahun 1992 (Asgari \& Darestani, 2017). Tujuan dari sistem evaluasi kinerja ini adalah untuk menciptakan motivasi bagi para eksekutif dan karyawan untuk mengejar tujuan keuangan dan non-keuangan, dan pada akhirnya akan mencapai keseimbangan antara kepentingan jangka pendek dan jangka panjang.

Kaplan dan Norton memperkenalkan BSC yang mengukur kinerja organisasi melalui empat perspektifnya di bidang keuangan, pelanggan, operasi internal, serta pembelajaran dan pertumbuhan perusahaan. Tujuannya adalah untuk menangkap langkah-langkah keuangan jangka pendek serta tujuan strategis jangka panjang dari perusahaan (Modak, Pathak, \& Ghosh, 2017). Balanced Scorecard tersebut tidak hanya menyediakan pengukuran kinerja, akan tetapi juga membantu perancang untuk mengidentifikasi apa yang seharusnya dilaksanakan dan diukur. Hal tersebut membantu para eksekutif untuk melaksanakan strategi-strategi mereka secara nyata (Rufaidah, 2012).

Ciri-ciri Balanced Scorecard mengandung unsur-unsur sebagai berikut, yaitu: (i) menetapkan ukuran kinerja secara kuantitatif, seperti tujuan dan ukurannya, serta dilakukan proses komunikasi antar tingkat manajemen dalam penyusunannya; (ii) mengevaluasi hasil kinerja secara berkelanjutan untuk melakukan perbaikan pengukuran kinerja pada kesempatan selanjutnya; dan (iii) mengintegrasikan hasl penetapan kinerja dan ukurannya kedalam suatu strategi perusahaan sehingga terintegrasi (Rufaidah, 2012).

Adapun kelebihan dan kekurangan dari BSC dirangkum sebagai berikut (Asgari \& Darestani, 2017). Kelebihannya adalah: (a) mencerminkan keseimbangan antara tujuan jangka pendek dan jangka panjang, ukuran keuangan dan non-keuangan, indicator tertinggal dan unggul serta perspektif kinerja eksternal dan internal; (b) melacak hasil keuangan sambil memantau kemajuan dalam membangun kemampuan dan memperolehaset tidak berwujud yang mereka perlukan untuk pertumbuhan di masa depan; dan (c) menempatkan strategi dan visi, bukan kontrol, di pusat. Serta kelemahannya adalah: (a) menunjukkan masalah, tetapi tidak mengungkapkan solusinya; dan (b) tidak termasuk perspektif pesaing.

\section{Analytical Hierarchy Process (AHP)}

Analytical Hierarchy Process (AHP) digunakan dalam menyederhanakan masalah yang kompleks dan tidak terstruktur, strategik dan dinamik menjadi bagian-bagian, serta menjadikan variabel dalam suatu tingkatan hirarki. Metode Analytical Hierarchy Process (AHP) dikembangkan oleh Thomas L. Saaty dan merupakan salah satu metode yang dapat digunakan dalam pengambilan keputusan dengan memperhatikan faktor-faktor persepsi, preferensi, pengalaman dan intuisi. Metode ini juga menggabungkan kekuatan dari perasaan dan logika 
pada berbagai persoalan, lalu mensintesis berbagai pertimbangan yang beragam menjadi hasil yang cocok dengan perkiraan kita secara intuitif sebagai mana yang dipresentasikan pada pertimbangan yang telah dibuat (Sumani, 2013).

Saaty (1994: 202) menyatakan bahwa ada tiga prinsip dasar dalam metode AHP, yaitu: 1) Dekomposisi. Setelah masalah telah didefinisikan, dekomposisi perlu dilakukan, yang membagi masalah menjadi beberapa bagian yang lebih kecil. Proses pembagian akan menghasilkan beberapa level masalah. Itu sebabnya proses analisis ini dinamai hierarki; 2) Penilaian Komparatif. Prinsip ini menilai kepentingan relatif dari dua elemen dalam level tertentu yang terkait dengan elemen di level yang lebih tinggi. Penilaian ini adalah poin utama dari metode AHP karena memengaruhi prioritas elemen. Hasil penilaian ini dapat diamati lebih baik jika ditampilkan dalam bentuk Pairwise Comparison Matrix; 3) Sintesis Prioritas Dari setiap Matriks Perbandingan Berpasangan, nilai vektor eigen dapat ditentukan untuk memperoleh prioritas lokal. Karena Pairwise Comparison Matrix tersedia di setiap level, prioritas global dapat diperoleh dengan mensintesiskan antara prioritas lokal tersebut. Prosedur penentuan ukuran berbeda menurut masing-masing hierarki. Untuk menentukan peringkat elemen sesuai dengan kepentingan relatifnya melalui prosedur sintesis disebut pengaturan prioritas.

\section{Pengukuran SkorKinerja dan Traffic Light System}

Pemberian skor dilakukan oleh pihak perusahaan, dengan mengikuti aturan sebagai berikut (Sulisworo \& Nurmaningsih, 2011): (a) Skor 7-10 : tolak ukur keberhasilan yang bersangkutan memiliki kinerja yang baik dengan syarat bila kelas pencapaian lebih besar dari target yang dicapai pada suatu periode; (b) Skor 4-6 : tolak ukur keberhasilan yang bersangkutan memiliki kinerja yang sedang dengan syarat apabila kelas pencapaian sama dengan target yang telah dicapai pada suatu periode; dan (c) Skor 0-3 : tolak ukur keberhasilan yang bersangkutan memiliki kinerja yang rendah dengan syarat bila kelas pencapaian sama dengan target yang dicapai pada satu periode.

Pengelompokan skor diatas juga berlaku untuk menilai rata-rata kinerja perusahaan pada masing-masing perspektif (Sodikin, Wisnubroto \& Ayunin, 2017): (a) Skor 7,1-10,0 : perusahaan memiliki kinerja yang baik dipandang dari perspektif yang bersangkutan; (b) Skor 3,1 - 7,0 : perusahaan memiliki kinerja yang sedang dipandang dari perspektif yang bersangkutan; dan (c) Skor 0,0-3,0 : perusahaan memiliki kinerja yang kurang baik dipandang dari perspektif yang bersangkutan.

Traffic Light System berfungsi sebagai tanda apakah indikator kinerja memerlukan suatu perbaikan atau tidak. Traffic Light System ini direpesentasikan dalam tiga warna (Sodikin, Wisnubroto \& Ayunin, 2017) yaitu: (1) Warna hijau, dengan ambang batas 7,1 - 10 yang berarti achievement dari suatu indikator kinerja sudah tercapai; (2) Warna kuning, dengan ambang batas 3,1 - 7 yang berarti achievement dari suatu indikator kinerja belum tercapai meskipun nilai sudah mendekati target; dan (3) Warna merah, dengan ambang batas lebih kecil atau sama dengan 3 yang berarti achievement dari suatu indikator kinerja benar-benar di bawah target yang telah ditetapkan dan memerlukan perbaikan dengan segera.

\section{METODOLOGI PENELITIAN}

Sampel dalam penelitian ini adalah manajer, karyawan dan pelanggan dari PT. IndoRama Synthetics Tbk. Jumlah keseluruhan populasi manajer sebanyak 27 departemen, jumlah populasi karyawan sebanyak 1.791, dan jumlah populasi pelanggan sebanyak 35. Sampel manajer keseluruhan sebesar 20 responden, sampel karyawan keseluruhan sebesar 332 responden dan sampel dari keseluruhan pelanggan domestik PT. Indo-Rama Synthetics Tbk. sebanyak 35 responden. Perhitungan pembobotan dilakukan secara komputasi menggunakan software Expert Choice versi 11. 


\section{ANALISIS DAN BAHASAN TEMUAN}

\section{Analisis Data Analytical Hierarchy Process (AHP)}

Berdasarkan hasil pembobotan perspektif Balanced Scorecard dalam penelitian ini dapat terlihat pada Tabel 1 dibawah ini.

Tabel 1. Rekapitulasi Pembobotan Perspektif Balanced Scorecard

\begin{tabular}{|c|c|c|c|c|c|}
\hline Perspektif & Bobot & Strategi Objective & Bobot & Ranking & $\begin{array}{c}\text { Target } \\
\text { Perusahaan }\end{array}$ \\
\hline \multirow{4}{*}{ Finansial } & \multirow{4}{*}{0,306} & Rasio solvabilitas & 0,0604 & 8 & $70,00 \%$ \\
\hline & & Rasio Iikuiditas & 0,0941 & 4 & $100,00 \%$ \\
\hline & & Rasio profitabilitas & 0,0949 & 3 & $0,20 \%$ \\
\hline & & Rasio aktivitas & 0,0566 & 9 & $80,00 \%$ \\
\hline \multirow{3}{*}{ Pelanggan } & \multirow{3}{*}{0,360} & Kualitas layanan & 0,1684 & 1 & 3,50 \\
\hline & & Penguasaan Pasar & 0,0830 & 5 & $4 \%$ \\
\hline & & Dukungan pelanggan & 0,1085 & 2 & 3,50 \\
\hline \multirow{2}{*}{$\begin{array}{l}\text { Proses Bisnis } \\
\text { Internal }\end{array}$} & \multirow{2}{*}{0,127} & $\begin{array}{c}\text { Karyawan yang berdisiplin dan } \\
\text { bertanggung jawab }\end{array}$ & 0,0773 & 6 & 3,50 \\
\hline & & Lingkungan kerja dan organisasi & 0,0497 & 11 & 3,50 \\
\hline \multirow{4}{*}{$\begin{array}{l}\text { Pembelajaran } \\
\text { \& Pertumbuhan }\end{array}$} & \multirow{4}{*}{0,207} & Kapabilitas kerja & 0,0501 & 10 & 3,50 \\
\hline & & Motivasi kerja karyawan & 0,0611 & 7 & 3,50 \\
\hline & & Fasilitas pendukung & 0,0463 & 13 & 4,00 \\
\hline & & Produktivitas kerja karyawan & 0,0494 & 12 & 1.000 \\
\hline
\end{tabular}

Sumber : Hasil Olah Data (2018)

Pada Tabel 1 tersebut menunjukkan bahwa perspektif "Pelanggan" dan "Finansial" adalah perspektif kunci yang sangat mendorong kinerja PT. Indo-Rama Synthetics Tbk. Selain itu, "Kualitas layanan," "Dukungan pelanggan," "Rasio profitabilitas," "Rasio likuiditas" dan "Penguasaan pasar" adalah lima kriteria pertama untuk evaluasi kinerja PT. Indo-Rama Synthetics Tbk., yang mencakup 36\% dari perspektif "Pelanggan".Hal inisesuai dengan kebijakan strategis perusahaan, dimana fokusnya adalah pada memelihara kepuasan pelanggan yang tersebar luas di seluruh dunia demi menjaga keseimbangan antara pasokan dan permintaan, yang melindungi kinerja bisnis bahkan di masa-masa sulit (PT. Indo-Rama Synthetics Tbk, 2018).

Analisis bobot dari perspektif finansial menggunakan Analytical Hierarchy Process (AHP) adalah 0,306, dan perhitungan menggunakan formula debt ratio, current ratio, return on assets (ROA), dan total assets turnover (TAT), dapat direkapitulasi sebagaiberikut.

Tabel 2. Rekapitulasi Perspektif Finansial

\begin{tabular}{|c|c|c|r|c|c|c|}
\hline Strategi Objective & Bobot & Target & Pencapaian & $\begin{array}{c}\text { \% } \\
\text { Pencapaian }\end{array}$ & Skor & Nilai \\
\hline Rasio solvabilitas & 0,203 & 70 & 65,31 & $7,18 \%$ & 7 & 1,4186 \\
\hline Rasio Iikuiditas & 0,279 & 100 & 106,98 & $6,98 \%$ & 7 & 1,9562 \\
\hline Rasio profitabilitas & 0,313 & 0,20 & 0,57 & $185,00 \%$ & 10 & 3,1290 \\
\hline Rasio aktivitas & 0,205 & 80 & 88,10 & $10,13 \%$ & 7 & 1,4357 \\
\hline Jumlah & 1,000 & \multicolumn{5}{|c|}{ Nilai Total } \\
\hline
\end{tabular}

Sumber : Hasil Olah Data (2018)

Berdasarkan Tabel 2 rasio profitabilitas mendapatkan nilai yang paling tinggi sebesar $(3,1290)$. Nilai total untuk perspektif finansial sebesar 7,94, dapat disimpulkan bahwa berdasarkan perspekif finansial PT. Indo-Rama Synthetics Tbk. memiliki kinerja yang baik.

Analisis bobot dari perspektif pelanggan menggunakan Analytical Hierarchy Process (AHP) adalah 0,360, dan perhitungan pengukuran perspektif pelanggan berdasarkan tiga indikator, yaitu kualitas layanan, penguasaan pasar dan dukungan pelanggan, dapat direkapitulasi sebagai berikut. 
Tabel 3. Rekapitulasi Perspektif Pelanggan

\begin{tabular}{|c|c|c|r|c|c|c|}
\hline Strategi Objective & Bobot & Target & $\begin{array}{c}\text { Kelas } \\
\text { Pencapaian }\end{array}$ & $\begin{array}{c}\text { \% } \\
\text { Pencapaian }\end{array}$ & Skor & Nilai \\
\hline Kualitas layanan & 0,502 & 3,5 & 3,98 & $13,71 \%$ & 7 & 3,5137 \\
\hline Penguasaan Pasar & 0,249 & 4 & 12,91 & $222,75 \%$ & 10 & 2,4930 \\
\hline Dukungan pelanggan & 0,248 & 3,5 & 4,01 & $14,57 \%$ & 7 & 1,7371 \\
\hline Jumlah & 0,999 & \multicolumn{7}{|c|}{ Nilai Total } & 7,7437 \\
\hline
\end{tabular}

Sumber : Hasil Olah Data (2018)

Berdasarkan hasil perhitungan Tabel diatas, semua rasio yang didapatkan dari perspektif pelanggan sudah mencapai dari target yang ditetapkan oleh perusahaan. Kualitas layanan mendapatkan nilai yang paling tinggi sebesar $(3,5137)$. Nilai total untuk perspektif pelanggan sebesar 7,74, dapat disimpulkan bahwa perspekif pelanggan pada PT. Indo-Rama Synthetics Tbk. memiliki kinerja yang baik.

Analisis bobot dari perspektif Proses Bisnis Internal menggunakan Analytical Hierarchy Process (AHP) adalah 0,127, dan perhitungan pengukuran perspektif Proses Bisnis Internal berdasarkan dua indikator, yaitu Karyawan yang berdisiplin dan bertanggung jawab dan Lingkungan kerja dan organisasi, dapat direkapitulasi sebagai berikut.

Tabel 4. Rekapitulasi Perspektif Proses Bisnis Internal

\begin{tabular}{|l|c|c|r|c|c|c|}
\hline \multicolumn{1}{|c|}{ Strategi Objective } & Bobot & Target & $\begin{array}{c}\text { Kelas } \\
\text { Pencapaian }\end{array}$ & $\begin{array}{c}\% \\
\text { Pencapaian }\end{array}$ & Skor & Nilai \\
\hline $\begin{array}{l}\text { Karyawan yang berdisiplin } \\
\text { dan bertanggung jawab }\end{array}$ & 0,628 & 3,5 & 3,99 & $14,00 \%$ & 7 & 4,3988 \\
\hline $\begin{array}{l}\text { Lingkungan kerja dan } \\
\text { organisasi }\end{array}$ & 0,372 & 3,5 & 3,89 & $11,14 \%$ & 7 & 2,6012 \\
\hline \multicolumn{1}{|c|}{ Jumlah } & 1,000 & \multicolumn{6}{|c|}{ Nilai Total } & 7,0000 \\
\hline
\end{tabular}

Sumber : Hasil Olah Data (2018)

Berdasarkan hasil perhitungan Tabeldiatas, semua rasio yang didapatkan dari perspektif proses bisnis internal sudah mencapai dari target yang ditetapkan oleh perusahaan. Karyawan yang berdisiplin dan bertanggung jawab mendapatkan nilai yang paling tinggi sebesar 4,3988. Nilai total untuk perspektif proses bisnis internal sebesar 7,00, dapat disimpulkan bahwa perspekif proses bisnis internal pada PT. Indo-Rama Synthetics Tbk. memiliki kinerja yang sedang.

Analisis bobot dari perspektif Pembelajaran \& Pertumbuhan menggunakan Analytical Hierarchy Process (AHP) adalah 0,207, dan perhitungan pengukuran perspektif Pembelajaran \& Pertumbuhan berdasarkan empat indikator, yaitu Kapabilitas kerja, Motivasi kerja karyawan, Fasilitas pendukung, dan Produktivitas kerja karyawan Kapabilitas kerja, Motivasi kerja karyawan, Fasilitas pendukung, dan Produktivitas kerja karyawan, dapat direkapitulasi sebagai berikut.

Tabel 5. Rekapitulasi Perspektif Pembelajaran dan Pertumbuhan

\begin{tabular}{|c|c|c|c|c|c|c|}
\hline Strategi Objective & Bobot & Target & $\begin{array}{c}\text { Kelas } \\
\text { Pencapaian }\end{array}$ & $\begin{array}{c}\% \\
\text { Pencapaian }\end{array}$ & Skor & Nilai \\
\hline Kapabilitas kerja & 0,283 & 3,5 & 3,87 & $10,57 \%$ & 7 & 1,9814 \\
\hline Motivasi kerja karyawan & 0,261 & 3,5 & 3,67 & $4,86 \%$ & 7 & 1,8291 \\
\hline Fasilitas pendukung & 0,207 & 4,00 & 3,53 & $-11,75 \%$ & 3 & 0,6195 \\
\hline $\begin{array}{l}\text { Produktivitas kerja } \\
\text { karyawan }\end{array}$ & 0,249 & 1000 & 2447,08 & $144,71 \%$ & 10 & 2,4920 \\
\hline Jumlah & 1,000 & & \multicolumn{3}{|c|}{ Nilai Total } & 6,9220 \\
\hline
\end{tabular}

Sumber : Hasil Olah Data (2018)

Berdasarkan hasil perhitungan Tabel diatas, semua rasio yang didapatkan dari perspektif Pembelajaran dan Pertumbuhan sudah mencapai dari target yang ditetapkan oleh perusahaan kecuali fasilitas pendukung. Produktivitas kerja karyawan mendapatkan nilai yang paling tinggi sebesar 2,4920. Nilai total untuk perspektif Pembelajaran \& Pertumbuhan sebesar 6,92, 
dapat disimpulkan bahwa perspekif Pembelajaran \& Pertumbuhan pada PT. Indo-Rama Synthetics Tbk. memiliki kinerja yang sedang.

\section{Analisis Data Balanced Scorecard (BSC)}

Perhitungan pengukuran kinerja berdasarkan empat perspektif dari Balanced Scorecard (BSC), yaitu keuangan, pelanggan, proses bisnis internal dan pembelajaran dan pertumbuhan, dapat direkapitulasi sebagai berikut.

Tabel 6. Rekapitulasi Hasil Pengukuran Kinerja

\begin{tabular}{|c|c|c|c|c|c|c|c|c|}
\hline Perspektif & Bobot & Strategi Objective & Bobot & $\begin{array}{c}\text { Target } \\
\text { Perusahaan }\end{array}$ & $\begin{array}{c}\text { Kelas } \\
\text { Pencapaian }\end{array}$ & $\begin{array}{c}90 \\
\text { Pencapaian }\end{array}$ & Skror & $\begin{array}{c}\text { Nilai } \\
\text { (Bobot } x \\
\text { Slkor) } \\
\end{array}$ \\
\hline \multirow{4}{*}{ Finansial } & \multirow{4}{*}{0,306} & Rasio solvabilitas & 0,0604 & $70,00 \%$ & $65,31 \%$ & $7,18 \%$ & 7 & 0,4228 \\
\hline & & Rasio Iikuiditas & 0,0941 & $100,00 \%$ & $106,98 \%$ & $6,98 \%$ & 7 & 0,6587 \\
\hline & & Rasio profitabilitas & 0,0949 & $0,20 \%$ & $0,57 \%$ & $185,00 \%$ & 10 & 0,949 \\
\hline & & Rasio aktivitas & 0,0566 & $80,00 \%$ & $88,10 \%$ & $10,13 \%$ & 7 & 0,3962 \\
\hline \multirow{3}{*}{ Pelanggan } & \multirow{3}{*}{0,36} & Kualitas layanan & 0,1684 & 3,5 & 3,98 & $13,71 \%$ & 7 & 1,1788 \\
\hline & & Penguagaan Pasar & 0,083 & $4 \%$ & $12,91 \%$ & $222,75 \%$ & 10 & 0,83 \\
\hline & & Dukungan pelanggan & 0,1085 & 3,5 & 4,01 & $14,57 \%$ & 7 & 0,7595 \\
\hline \multirow{2}{*}{$\begin{array}{l}\text { Proses Bisnis } \\
\text { Internal }\end{array}$} & \multirow[t]{2}{*}{0,127} & $\begin{array}{c}\text { Raryawan yang } \\
\text { berdisiplin dan } \\
\text { bertanggung jawab }\end{array}$ & 0,0773 & 3,5 & 3,99 & $14,00 \%$ & 7 & 0,5411 \\
\hline & & $\begin{array}{l}\text { Lingkungan kerja } \\
\text { dan organisasi }\end{array}$ & 0,0497 & 3,5 & 3,89 & $11,14 \%$ & 7 & 0,3479 \\
\hline \multirow{4}{*}{$\begin{array}{c}\text { Pembelajaran } \\
\& \\
\text { Pertumbuhan }\end{array}$} & \multirow{4}{*}{0,207} & Kapabilitas kerja & 0,0501 & 3,5 & 3,87 & $10,57 \%$ & 7 & 0,3507 \\
\hline & & $\begin{array}{c}\text { Motivasi kerja } \\
\text { karyawan }\end{array}$ & 0,0611 & 3,5 & 3,67 & $4,86 \%$ & 7 & 0,4277 \\
\hline & & Fasilitas pendukung & 0,0463 & 4 & 3,53 & $-11,75 \%$ & 3 & 0,1389 \\
\hline & & $\begin{array}{c}\text { Produktivitas kerja } \\
\text { karyawan }\end{array}$ & 0,0494 & 1.000 & 2.447 & $144,71 \%$ & 10 & 0,494 \\
\hline \multicolumn{3}{|c|}{ Jumlah } & 1,000 & & & & & 7,495 \\
\hline
\end{tabular}

Sumber : Hasil Olah Data (2018)

Berdasarkan Tabel 5 pengukuran kinerja menggunakan AHP dan balanced scorecard, nilai skor dari ke-empat perspektif adalah 7,495. Hal ini menandakan perusahaan berada dilevel baik. Adapun indikator yang perlu menjadi perhatian lebih bagi perusahaan adalah fasilitas pendukung. Pada indikator tersebut kinerja perusahaan memiliki hasil yang di bawah target dari perusahaan.

\section{Analisis Data Traffic Light System}

Setelah melakukan evaluasi terhadap hasil perhitungan kinerja secara keseluruhan, selanjutnya dilakukan evaluasi menggunakan traffic light system, dapat terlihat pada Tabel 7 dibawah ini:

Tabel 7. Traffic Light System

\begin{tabular}{|c|c|c|}
\hline Index Total & Perspektif & Strategy Objective \\
\hline \multirow{13}{*}{7,495} & \multirow{4}{*}{ Finansial $(7,94)$} & Rasio Solvabilitas $(7,00)$ \\
\hline & & Rasio Likuiditas $(7,00)$ \\
\hline & & Rasio Profitabilitas $(10,00)$ \\
\hline & & Rasio Aktivitas $(7,00)$ \\
\hline & \multirow[t]{3}{*}{ Pelanggan $(7,74)$} & Kualitas Layanan $(7,00)$ \\
\hline & & Penguasaan Pasar $(10,00)$ \\
\hline & & Dukungan pelanggan $(7,00)$ \\
\hline & \multirow[t]{2}{*}{$\begin{array}{l}\text { Proses Bisnis } \\
\text { Internal }(7,00)\end{array}$} & $\begin{array}{l}\text { Karyawan yang Berdisiplin dan } \\
\text { Bertanggung Jawab }(7,00)\end{array}$ \\
\hline & & Lingkungan Kerja dan Organisasi $(7,00)$ \\
\hline & \multirow{4}{*}{$\begin{array}{c}\text { Pembelajaran dan } \\
\text { pertnrnbuhan }(6,92)\end{array}$} & Kapabilitas Kerja $(7,00)$ \\
\hline & & Motivasi kerja karyawan $(7,00)$ \\
\hline & & Fasilitas pendukung $(3,00)$ \\
\hline & & Produktivitas kerja karyawan $(10,00)$ \\
\hline
\end{tabular}

Sumber : Hasil Olah Data (2018)

Berdasarkan traffic light systempada Tabel 7 keseluruhan index total PT. Indo-Rama Synthetics Tbk. adalah 7,495 memiliki warna hijau, artinya kinerja perusahaan telah mencapai 
kinerja yang diharapkan. Setiap objektif memiliki berbagai warna yang beragam. Perspektif finansialdan perspektif pelanggan telah mencapai skor yang tinggi dengan skor 7,94 dan 7,75. Diikuti dengan perspektif proses bisnis internal dengan skor 7,00 dan perspektif pembelajaran dan pertumbuhan dengan skor 6,92 .

\section{KESIMPULAN DAN REKOMENDASI Kesimpulan}

Hasil penelitian menyatakan bahwa, (1) Berdasarkan hasil pembobotan Perspektif Balanced Scorecard menggunakan Analytical Hierarchy Process (AHP), perspektif Pelanggan dan Finansial adalah perspektif kunci yang sangat mendorong kinerja PT. Indo-Rama Synthetics Tbk, dengan bobot masing-masing sebesar 0,360 dan 0,306; (2) Hasil pengukuran kinerja berdasarkan skor dari empat perspektif Balanced Scorecard (BSC), yaitu keuangan (finansial), pelanggan, dan proses bisnis internal memiliki kinerja baik, sedangkan perspektif pembelajaran dan pertumbuhan memiliki kinerja sedang; dan (3) Berdasarkan traffic light system, secara keseluruhan index total kinerja PT. Indo-Rama Synthetics Tbk. adalah 7,495 memiliki warna hijau, artinya perusahaan telah mencapai kinerja yang diharapkan.

\section{Saran}

Berdasarkan hasil penelitian, maka penulis menyarankan beberapa hal sebagai berikut:

1. Berdasarkan hasil pembobotan Perspektif Balanced Scorecard menggunakan Analytical Hierarchy Process (AHP), perspektif pelanggan merupakan perspektif kunci yang sangat penting dalam pengembangan PT. Indo-Rama Synthetics Tbk. dan dapat membimbing perusahaan untuk berkembang di sepanjang arah yang berkelanjutan. Untuk itu beberapa hal yang dapat dilakukan antara lain: (a) Memenuhi kebutuhan dan permintaan sesuai dengan keinginan pelanggan; (b) Melakukan evaluasi secara kontinyu terhadap pelayanan kepada pelanggan; (c) Meningkatkan dan menjaga kualitas produk yang dihasilkan; dan (d) Memperhatikan dan menjaga hubungan yang baik dengan pelanggan.

2. Berdasarkan perhitungan pengukuran skor kinerja berdasarkan perspektif dari Balanced Scorecard (BSC), perspektif pembelajaran dan pertumbuhan memiliki kinerja sedang. Untuk itu beberapa hal dapat dilakukan antara lain: (a) Lebih memperhatikan dan menanggapi keluhan karyawan dengan melengkapi fasilitas pendukung; dan (b) Memberikan pelatihan yang benar-benar dibutuhkan oleh para karyawan sehingga karyawan memiliki kapabilitas yang baik.

3. Berdasarkan traffic light system, fasilitas pendukung menunjukan kinerja yang sangat buruk. Untuk itu beberapa hal dapat dilakukan antara lain: (a) Memenuhi kebutuhan dan permintaan karyawan yang berkaitan dengan fasilitas dalam bekerja; dan (b) Melakukan evaluasi secara kontinyu terhadap pelayanan kepada karyawan.

\section{DAFTAR PUSTAKA}

Addo. 2018. Strategi Indonesia Memasuki Industri 4.0 Melalui 5 Sektor Manufaktur. diakses 10/8/2018 melalui http://jakartainsight.com/read/artikel/2018/04/03/2316/StrategiIndonesia-Memasuki-Industri-4.0-Melalui-5-Sektor-Manufaktur.

Asgari, N., \& Darestani, S. A. (2017). Application of multi-criteria decision making methods for balanced scorecard: a literature review investigation. International Journal of Services and Operations Management, 27(2), 262-283.

Azmi, R.A. (2018). Profile PT. Indo-Rama SYNTHETICS Tbk, diakses 10/8/2018 melalui https://www.scribd.com/doc/310142350/Profile-PT-Indo-Rama-SYNTHETICS-Tbkpdf

Harjanto, E. 2009. Sains manajemen: Analisis kuantitatif untuk pengambilan keputusan. Jakarta: Grasindo.5

Iswanto, D, 2017, Manufaktur Tumbuh Melambat, Sektor Jasa Dominan terhadap PDB diakses 10/8/2018 melalui https://akurat.co/id-94888-read--manufaktur-tumbuh-melambat- 
sektor-jasa-dominan-terhadap-pdb.

Modak, M., Pathak, K., \& Ghosh, K. K. (2017). Performance evaluation of outsourcing decision using a BSC and Fuzzy AHP approach: A case of the Indian coal mining organization. Resources Policy, 52, 181-191.

Rufaidah, P. (2012). Manajemen Strategik. Edisi Pertama. Bandung : Humaniora.

Sodikin, I., Wisnubroto, P., \& Ayunin, N. M. (2017). Pengukuran kinerja perusahaan menggunakan Strategic Management Analysis and Reporting Technique (SMART) System di PT Telkom Witel Magelang. Industrial Engineering Journal of The University of Sarjanawiyata Tamansiswa, 1(1). 9-16.

Sulisworo, D., \& Nurmaningsih, S. (2011). Pembobotan sasaran strategis perspektif balance scorecard (BSC) pada perusahaan air minum. Jurnal Ilmiah Teknik Industri, 10(1), 2228.

Sumani. (2016). Pengukuran kinerja bisnis melalui pendekatan balanced scorecard dan analytical hierarchy process (AHP). EKUITAS: Jurnal Ekonomi dan Keuangan, 20(4), 455-472.Education, 2(8), 68-70. 